\title{
深圳市海绵城市的建设与创新
}

\author{
刘 建 ${ }^{1}$ ，龚小强 ${ }^{1}$ ，任心欣 ${ }^{2}$ ，刘程飞 ${ }^{3}$ ，吴凌壹 ${ }^{1}$ ，吴亚男 ${ }^{2}$
}

1）深圳大学建设工程生态技术研究所，广东深圳 $518060 ； 2 ）$ 深圳市城市规划设计研究院有限公司，广东深圳 518031 ;

3 ）深圳市海绵城市建设办公室，广东深圳 518036

摘 要: 简述了中国深圳市海绵城市建设情况, 总结了深圳市海绵城市建设经验与教训, 结合政策文 件和工程案例, 论述了深圳市海绵城市创新成果. 组织创新主要包括组建市级、区级海绵城市建设工作领 导小组、成立海绵城市建设技术联盟和设立院士工作站; 管理创新包括制度和标准的制订等内容; 技术创 新主要讨论了海绵城市设施创新和海绵介质土创新. 考虑到海绵城市设施的应用范围, 分别介绍了适用于 建筑小区、城市道路、地铁车辆段和城市更新项目的创新型海绵城市设施案例. 这些案例包括深圳大学土 木结构实验楼海绵城市设施、南山区登良路海绵城市设施、深圳地铁 6 号线长圳车辆段海绵城市设施，以 及光明区甲子塘村城中村综合整治项目海绵城市设施.

关键词：海绵城市；低影响开发；技术创新；生态屋顶；雨水花园；高位雨水花坛; 海绵介质土; 深圳

中图分类号：TV512 文献标志码：A doi：10.3724/SP. J. 1249.2020.04334

\section{Sponge city construction and innovation in Shenzhen}

\section{LIU Jian ${ }^{1}$, GONG Xiaoqiang ${ }^{1}$, REN Xinxin ${ }^{2}$, LIU Chengfei ${ }^{3}$, WU Lingyi ${ }^{1}$, and WU Ya'nan ${ }^{2}$}

1) Ecological Technology Institute of Construction Engineering, Shenzhen University, Shenzhen 518060, Guangdong Province, P. R. China

2) Urban Planning \& Design Institute of Shenzhen, Shenzhen 518031, Guangdong Province, P. R. China 3 ) Shenzhen Sponge City Construction Office, Shenzhen 518036, Guangdong Province, P. R. China

\begin{abstract}
This paper briefly introduces the background and achievements of the sponge city construction in Shenzhen, China, and summarizes the experience and lessons in the construction of sponge city and discusses the innovation achievements of the sponge city in Shenzhen, combining the policy documents and engineering cases. The organizational innovation mainly comprises the formation of leading teams of municipal and district sponge city construction work, establishment of sponge city construction technology alliance and setting up academician workstation; the management innovation includes the policy making and establishment of technology standards; and the technological innovation mainly discusses the innovation of sponge city facility and mixing soil. Considering the application scope of the sponge city facilities, this paper introduces the innovative sponge city facilities, which are suitable for building district, urban road, metro depot and urban renewal projects. The case studies include: (1) sponge city facilities of the civil engineering experimental building in Shenzhen University; (2) sponge city facilities on the Dengliang Road in Nanshan District; (3) sponge city facilities of the Changzhen Depot of Shenzhen Metro Line 6 in Guangming District;

Received: 2020-05-11; Accepted: 2020-05-18

Foundation: National Key R \& D Program of China (2018YFB2100901)

Corresponding author: Experimentalist WU Lingyi. E-mail: szuly@ szu.edu.cn

Citation: LIU Jian, GONG Xiaoqiang, REN Xinxin, et al. Sponge city construction and innovation in Shenzhen [J]. Journal of Shenzhen University Science and Engineering, 2020, 37(4) : 334-346. (in Chinese)
\end{abstract}


(4) sponge city facilities of comprehensive renovation project in Jiazitang Village, Guangming District.

Key words : sponge city; low impact development; technology innovation; ecoroof; rain garden; elevated bioretention cell; mixing soil of sponge city; Shenzhen

20 世纪 70 至 80 年代，美国、英国、日本、澳 大利亚等发达国家为解决面源污染和城市内涝等城 市环境问题，相继开发了一系列绿色环保技术，如 美国的最佳管理实践 (best management practice, BMP)、低影响开发 (low impact development, LID) 和绿色基础设施 (green infrastructure, GI)，英国的 可持续排水系统 (sustainable urban drainage system, SUDS), 日本的雨水滞留储留设施, 澳大利亚的水 敏感性城市设计技术等. 这些技术经过不断完善， 已在所在国广泛应用, 并逐渐推广到其他国家 ${ }^{[1-2]}$.

中国城镇化的快速进程对推动经济社会发展和 提高人民生活质量起到了极为重要的作用，但也导 致了城市内涝积水、黑臭水体产生、水资源短缺等 影响城市人居环境和社会经济可持续发展的突出问 题，严重制约了城市的高质量发展. 针对上述问 题，2013 年 12 月，习近平总书记在中央城镇化工 作会议上作了“优先考虑更多利用自然力量排水, 建设自然积存、自然渗透、自然净化的海绵城市” 重要讲话 ${ }^{[1]}$. 为了贯彻落实习近平总书记建设海绵 城市的重要讲话精神，2015 年 4 月、2016 年 4 月， 国家财政部、住建部和水利部分两批开展了中央财 政支持的海绵城市试点工作. 试点城市共计 30 个, 分别为 2015 年的迁安、白城、镇江、嘉兴、池州、 厦门、萍乡、济南、鹤壁、武汉、常德、南宁、重 庆、遂宁、贵安新区和西咸新区，2016 年的福州、 珠海、宁波、玉溪、大连、深圳、上海、庆阳、西 宁、三亚、青岛、固原、天津和北京（按区域排 序). 对这些试点城市，中央财政给予了 3 年的专 项资金补助，直辖市每年 6 亿元，省会城市每年 5 亿元，其他城市每年 4 亿元 ${ }^{[2]}$.

深圳是经济、产业和人口大市, 2018 年末全市 常住人口已超过 1300 万，国民生产总值超 2.4 万 亿元；同时也是空间资源和环境容量小市，境内无 大江大河，建设用地不足 $1000 \mathrm{~km}^{2}$. 随着城市超 常规发展，环境承载能力的先天不足与高度发达的 经济行为之间的失衡日益突出： $80 \%$ 以上用水依靠 境外引人；2016 年之前近一半河流为黑臭水体；城 市内涝问题比较突出; 水生态破坏严重 ${ }^{[3]}$. 如何处 理好城市发展和环境保护的关系，统筹好生产、生 活和生态 “三生空间”，实现高质量发展，可持续
发展，建成 “中国特色社会主义先行示范区” 是深 圳必须解决的当务之急. 正因如此, 深圳市委市政 府高度重视海绵城市建设. 2016 年 4 月, 深圳人选 国家第 2 批海绵城市建设试点城市，立即成立了由 主管副市长牵头、市政府相关各部门为成员单位的 深圳市海绵城市建设工作领导小组，并组建了市海 绵城市建设工作领导小组办公室 (简称市海绵办), 由市海绵办负责全市海绵城市建设工作的统筹协 调、技术指导和监督考核等工作，以国家试点为契 机，在全市域将海绵城市建设与 “治水”、“治城” 相融合，探索建立了法制化、标准化、常态化和社 会化的实施机制.

随着海绵城市建设由试点转向常态推进，总结 优秀的海绵城市建设项目经验，可以极大提高海绵 城市建设质量和效益. 尽管深圳 2016 年才人选为 国家海绵城市试点城市，但是，早在 2004 年深圳 就开始了海绵城市的研究和示范工程建设工作. 2008 年以来, 深圳市因地制宜研发了生态屋顶、蓝 色屋顶、建筑垃圾制成的透水铺装、多功能蓄水池 和环保雨水口等新型海绵城市设施，先后涌现出深 圳大学土木结构实验楼、登良路、万科云城、甲子 塘城中村综合整治项目海绵城市综合体，以及深圳 地铁 6 号线长圳车辆段等优秀的海绵城市项目，成 功建成了全面达到国家海绵城市要求、占地面积约 $16 \mathrm{~km}^{2}$ 的光明区凤凰城海绵片区.

本文梳理了深圳市海绵城市建设总体情况，总 结了深圳市进行海绵城市建设的经验及创新, 介绍 了深圳大学土木结构实验楼、南山区登良路、深圳 地铁 6 号线长圳车辆段以及光明区甲子塘城中村综 合治理项目的海绵城市设施.

\section{1 海绵城市建设规模及效果}

依据《财政部住房城乡建设部关于印发〈城市管 网专项资金管理办法 $\rangle$ 的通知》（财建 [2016] 863 号）规定，中央专项资金对深圳市每年补助 4 亿 元，共 3 年. 收到中央专项资金后，作为海绵城市 重点试点区域的光明区，结合《深圳市海绵城市建 设试点 3 年实施计划 $(2016-2018) 》$, 编制了海绵 城市建设试点 3 年的资金使用计划，逐项明确了 25 
个项目（政府投资建设项目 9 项，纳人政府和社会 资本合作 (public-private partnership，PPP) 建设项目 4 项，其他非建设项目 12 项）的支出范围和额度， 确保在海绵城市建设试点期内完成 $100 \%$ 的支出任 务. 原 3 年计划试点区域内政府投资项目中共有 25 项纳人中央专项资金支持范畴，25 个项目中 3.04 亿元不足资金由深圳市、区两级政府资金进行保 障，试点区域其他 52 个项目 37.08 亿元资金依靠 市区两级政府投资项目计划予以保障.

2016 年 4 月以来，深圳市海绵城市建设取得了 丰硕成果. 2017 和 2018 年，竣工的海绵城市项目 共 1361 个，包括建筑与小区类 351 个 ( 25.58 $\left.\mathrm{km}^{2}\right)$ 、道路与广场类 335 个 $\left(12.81 \mathrm{~km}^{2}\right)$ 、公园绿 地类 318 个 $\left(21.6 \mathrm{~km}^{2}\right)$ 、河流水系类 307 个 $\left(41.39 \mathrm{~km}^{2}\right)$ 、其他 50 个 $\left(3.18 \mathrm{~km}^{2}\right)$, 共新增海 绵城市面积 $104 \mathrm{~km}^{2[4-5]}$. 2019 年完工项目 912 个, 新增海绵城市面积 $91.76 \mathrm{~km}^{2[6]}$. 截至 2019 年 12 月，深圳市新增及改造海绵城市面积为 226.06 $\mathrm{km}^{2}$ ，占城市建成区面积的 $23 \%$ ，超额完成国家海 绵城市的目标 (20\%) 要求, 同时城市水环境大大 改善，全市 220 个历史内涝点问题已基本消除， 159 个黑臭水体全部得到治理 ${ }^{[7]}$.

2019 年 12 月，深圳市接受了国家海绵城市建 设试点绩效考核，考核成绩名列前茅.

\section{2 深圳市海绵城市建设经验}

深圳以“法制化、标准化、常态化、社会化” 为原则，积极探索建立了 “七全” 的海绵城市推进 模式，提升了城市精细化建设和管理水平，积累了 丰富的海绵城市建设经验. “七全” 指 “政府引领 全部门、规划指引全覆盖、技术支撑全视角、项目 管控全方位、广泛参与全社会、以点带面全市域、 布局建设全维度”。深圳市在全面推进海绵城市建 设的同时，注重政府引领，制定规范、政策和制度 文件，要求新建、改建、扩建建设项目严格按照海 绵城市要求进行规划、设计和建设 ${ }^{[8]}$. 其次, 实行 项目全生命周期的管理，全方位管控项目. 同时, 实施大量海绵城市建设举措, 大力发展创新技术, 支撑海绵城市建设，以试点带动全域海绵城市建 设，全维度布局海绵城市建设，打造海绵城市空间 格局; 鼓励全社会参与监督. 保障海绵城市建设 质量.

\section{1 规范和政策文件}

海绵城市建设涉及规划、建设、交通、园林、 环保和水务等城市建设的方方面面，良好的政策和 标准是有序推进海绵城市建设的重要保障. 因此, 市海绵办于 2016 年 8 月印发《深圳市推进海绵城 市建设工作实施方案》 (深海绵办 $[2016] 3$ 号)，理 顺海绵城市建设工作机制，明确各部门职责，如市 海绵办负责统筹协调，市委宣传部负责组织、落实 海绵城市的相关宣传和公众教育等工作; 市发展和 改革委员会负责制定 PPP 投融资模式相关政策，保 障投资需求; 市科技创新委员会负责海绵城市基础 研究的科研项目. 此后, 市海绵办陆续组织制订了 《关于市财政支持海绵城市建设实施方案 (试行)》 （深财居 [2018]7 号）、《深圳市海绵城市规划要点 和审查细则》、《海绵城市设计图集》等一系列政策 文件和技术指南,稳步推进海绵城市建设.

深圳市制订了一系列政策和规范性文件，有力 地推动了深圳市海绵城市建设. 截至 2019 年底, 深圳市已出台海绵城市法规或行政规范性文件 4 部 （表 1)，制度和政策文件 22 部（表 2).

表 1 深圳市海绵城市建设法规或行政规范性文件

Table 1 Regulations or administrative normative

documents on sponge city construction in Shenzhen

\begin{tabular}{|c|c|c|}
\hline 序号 & 名称 & 文号 \\
\hline 1 & $\begin{array}{l}\text { 《深圳市海绵城市建设管 } \\
\text { 理暂行办法》 }\end{array}$ & 深府办 [2018］12 号 \\
\hline 2 & $\begin{array}{l}\text { 《深圳市基本生态控制线 } \\
\text { 管理规定》 }\end{array}$ & $\begin{array}{l}\text { 深圳市人民政府令 } \\
\text { (第 } 145 \text { 号) }\end{array}$ \\
\hline 3 & $\begin{array}{l}\text { 《深圳市政府投资建设项 } \\
\text { 目施工许可管理规定》 }\end{array}$ & $\begin{array}{l}\text { 深圳市人民政府令 } \\
\text { (第310 号) }\end{array}$ \\
\hline 4 & $\begin{array}{l}\text { 《深圳市社会投资建设项 } \\
\text { 目报建登记实施办法》 }\end{array}$ & $\begin{array}{l}\text { 深圳市人民政府令 } \\
\text { (第 } 311 \text { 号) }\end{array}$ \\
\hline
\end{tabular}

\section{2 标准体系}

为保障海绵城市建设质量, 高标准打造了覆盖 深圳市海绵城市规划、设计、施工、维护、评价等 环节的政策技术标准体系，陆续出台了一系列海绵 城市技术标准和指南，具有先行先试的优势. 这些 标准和指南，不但有力地指导了深圳市海绵城市的 建设,也为全国海绵城市标准制订提供了借鉴.

截至 2019 年底，深圳市已制订地方标准、技 术导则 34 部，试点区域层面 6 部，全市层面 27 部 (表 3 )，涉及到规划 8 部、设计 13 部、设计审查 4 
部、施工验收运维 2 部. 标准充分体现了深圳地方 特色, 如与治水治城相融合的《深圳市正本清源行 动技术指南 (试行)》 (修订)、《深圳市城中村综
合治理标准指引》、《深圳市重点区域开发建设导 则》等技术标准.

\section{表 2 海绵城市建设制度和政策文件}

Table 2 Sponge city construction system and policy documents

\begin{tabular}{|c|c|c|}
\hline 序号 & 名 称 & 文 号 \\
\hline 1 & 《深圳市推进海绵城市建设工作实施方案》 & 深海绵办 [2016] 3 号 \\
\hline 2 & 《2017 年全市海绵城市建设工作任务分工》 & 深海绵办 [2017] 7 号 \\
\hline 3 & 《2018 年深圳市海绵城市建设工作任务分工》 & 深海绵办 $[2018] 45$ 号 \\
\hline 4 & 《2019 年深圳市海绵城市建设工作任务分工》 & 深海绵办 $[2019] 28$ 号 \\
\hline 5 & 《深圳市开展政府和社会资本合作试点的实施方案》 & 深府办 [2017] 16 号 \\
\hline 6 & 《深圳市海绵城市建设试点专项补助资金管理办法》 & 深财居 ［2017］11 号 \\
\hline 7 & 关于在政府投资项目前期阶段进一步加强海绵城市建设管理工作的通知 & 深海绵办 [2017] 90 号 \\
\hline 8 & $\begin{array}{l}\text { 《深圳市贯彻落实国务院办公厅关于进一步激发民间有效投资活力促进经济 } \\
\text { 持续健康发展指导意见的实施方案》 }\end{array}$ & 深府办 [2018］ 6 号 \\
\hline 9 & 《深圳市政府和社会资本合作（PPP）实施细则》 & 深发改规［2018］1 号 \\
\hline 10 & 《深圳市海绵城市建设试点工作专项督导整改工作方案》 & 深海绵办 $[2018] 43$ 号 \\
\hline 11 & 关于在建设项目施工图设计审查中加强海绵城市技术措施专项审查的通知 & 深海绵办 $[2018] 53$ 号 \\
\hline 12 & 《深圳市光明新区海绵城市规划建设管理办法（试行)》 & 深光海绵办 [2017］37 号 \\
\hline 13 & 《光明区海绵城市建设管理工作规程（试行)》 & 深光海绵办 [2019］14 号 \\
\hline 14 & 《深圳市 2018 年度绩效管理工作实施方案》 & 深绩委 [2018］1 号 \\
\hline 15 & 《深圳市 2019 年度绩效管理工作实施方案》 & 深绩委 [2019］ 2 号 \\
\hline 16 & 《深圳市 2018 年度生态文明建设考核实施方案》 & 深生考办 [2018］17 号 \\
\hline 17 & 《深圳市 2019 年度生态文明建设考核实施方案》 & 深生考办 [2019］25 号 \\
\hline 18 & 《深圳市海绵城市建设政府实绩考评办法》 & 深海绵办 $[2017] 79$ 号 \\
\hline 19 & 《深圳市海绵城市建设政府实绩考评实施细则 (2018 年)》 & 深海绵办 $[2018] 111$ 号 \\
\hline 20 & 《关于市财政支持海绵城市建设实施方案 (试行)》 & 深财居 [2018］７号 \\
\hline 21 & 《深圳市海绵城市建设资金奖励实施细则 (试行)》 & 深水规 [2018］4 号 \\
\hline 22 & 《深圳市海绵城市建设资金奖励申报指南 (2019 年)》 & 深海绵办 [2019］ 27 号 \\
\hline
\end{tabular}

表 3 深圳市海绵城市建设技术标准指南

Table 3 Technical standards and guidelines for Shenzhen sponge city construction

\begin{tabular}{clc}
\hline \multicolumn{1}{c}{ 名 称 } & 文 号 \\
\hline & 《深圳市海绵城市规划要点和审查细则》 (2019 年修订) & 深规划资源函 [2019] 1093 号 \\
& 《深圳市重点区域开发建设导则》 & 深重总指办 [2018]7 号 \\
& 《深圳市城市规划标准与准则》 (2013 版) & 深规土 [2013]776 号 \\
& 《深圳市法定图则编制技术指引》 & 深规土 [2014] 471 号 \\
规划 & 《深圳市城市规划低冲击开发技术指引》 & 印发稿 \\
& 《深圳市拆除重建类城市更新单元编制技术规定》(2018 年修订) & 深规土 [2018]708 号 \\
& 《深圳市绿色建筑评价标准》 (2018 年修订) & SJG 47-2018 \\
& 《深圳市建设工程规划许可 (房建类) 报建文件编制技术规定》 & 深规土 [2018]949 号 \\
\hline
\end{tabular}


(续表 3)

\begin{tabular}{|c|c|c|}
\hline 类 别 & 名 称 & 文 号 \\
\hline \multirow{13}{*}{ 设计 } & 《低影响开发雨水综合利用技术规范》 & $\mathrm{SZDB} / \mathrm{Z} 145-2015$ \\
\hline & 《雨水利用工程技术规范》 & $\mathrm{SZDB} / \mathrm{Z} 49-2011$ \\
\hline & 《再生水、雨水利用水质规范》 & SZJG 32-2010 \\
\hline & 《深圳市房屋建筑工程海绵设施设计规程》 & SJG 38-2017 \\
\hline & 《深圳市海绵型道路建设技术指引》 & 深交字 ［2018］625号 \\
\hline & 《深圳市海绵型公园绿地建设指引》 & - \\
\hline & 《深圳市水务工程项目海绵城市建设技术指引 (试行)》 & 深水函 [2018］67 号 \\
\hline & 《深圳市建筑工务署政府公共工程海绵城市建设工作指引》 & SZGWS Z02-2018 \\
\hline & 《深圳市正本清源行动技术指南 (试行)》( 修订) & 深治水办 [2018] 11 号 \\
\hline & 《深圳市暴雨强度公式》 & - \\
\hline & 《海绵城市设计图集》 & DB4403/T 24-2019 \\
\hline & 《深圳市开发建设项目水土保持方案（设计）报告书编制指南》（试行） & - \\
\hline & 《深圳市城中村综合治理标准指引》 & 深城提办 $[2018] 3$ 号 \\
\hline \multirow{4}{*}{ 设计审查 } & 《深圳市房屋建筑工程海绵设施施工图设计文件审查要点》 & 深建设 [2017］14 号 \\
\hline & 《深圳市道路建设工程海绵城市施工图设计审查要点 (试行)》 & 深交字 ［2018］624 号 \\
\hline & 《公园绿地海绵城市技术措施审图要点》 & - \\
\hline & 《深圳市水务类海绵城市施工图设计审查要点》 & 深水函 [2018］2508 号 \\
\hline 施工、验收、 & 《海绵城市建设项目施工、运行维护技术规程》 & DB4403/T 25-2019 \\
\hline 运维 & 《深圳市建设项目海绵设施验收工作要点及技术指引（试行)》 & 深海绵办 [2019] 70 号 \\
\hline
\end{tabular}

\section{3 项目全生命周期的管理}

为做好海绵城市建设项目管控工作，深圳市采 取项目全生命周期进行管控，对建设项目规划设 计、施工、验收、运行维护各环节进行全面把控, 并完善海绵城市建设长效机制, 建设海绵城市智慧 平台，全方位管控. 对海绵城市项目从立项、设 计、施工、验收到管养全生命周期进行管理. 通过 收集海绵城市项目的区域规划方案、设计、位置、 设施建设以及运营管养等资料，海绵城市建设管理 部门对项目进行全过程的跟踪, 了解项目的进展情 况，及时发现隐蔽工程存在的问题，实现对海绵城 市建设的有效评估和监控，提高海绵城市项目设计 和建设质量，保证整体效果.

为全面提高深圳市海绵城市建设和管理水平, 深圳市综合应用云计算、互联网 + 和地理信息系统 等科学手段建设深圳市海绵城市规划设计、工程建 设、运营管理的智慧化管理平台, 实现智慧化、系 统化、科学化、精细化管理; 并通过专业人员驻点
服务，强化人员力量和技术支持; 同时，通过成立 企业院士工作站、引进技术联盟成员单位及加强基 础研究等方式, 引智借力, 打造海绵城市科研平台.

\section{4 海绵城市建设举措}

在 “七全” 模式下，深圳市通过制定良好的政 策、规范和标准有效保证了海绵城市建设，实行项 目全生命周期管控，确保项目全过程质量，高效率 推进海绵城市建设.

\subsection{1 成立海绵办, 统筹协调海绵城市建设}

海绵城市的建设涉及到方方面面的工作和单 位，需要一个良好的工作机制保障海绵城市建设的 有序推进，市、区级海绵城市建设工作领导小组和 办公室应运而生,成员单位包括财政、水务、住建、 发改、规划和党委等 37 个部门和单位, 形成协作 推进平台，共同推动海绵城市建设，统筹推动海绵 城市建设的落地实施. 市海绵办负责全市海绵城市 建设工作的统筹协调等工作, 具体工作 ${ }^{[9]}$ 如下:

1) 协助领导小组安排部署深圳市海绵城市建 
设工作重大事项, 协调处理建设工作中涉及的重大 问题;

2) 制定我市海绵城市建设工作计划及任务分 解表, 并报领导小组审定;

3）组织协调全市海绵城市建设各项政策、标 准和规范性文件的制定;

4）负责协调、指导和督促有关责任单位和部 门开展海绵城市建设相关工作;

5）负责制定我市海绵城市建设绩效考评办法, 组织绩效考核;

6) 组织我市海绵城市建设的宣传和培训工作.

\subsection{2 多尺度融合，打造海绵城市空间格局}

海绵城市的建设需以跨尺度的生态规划理论和 方法体系为基础, 海绵城市的构建需要宏观层面、 中观层面、微观层面不同尺度的承接、配合, 多种 海绵空间相互关联, 形成多尺度、立体、交融的体 系. 深圳市高度重视海绵城市建设与水污染治理、 内涝治理等的融合, 实施雨污分流改造、黑臭水体 治理、防洪标准提升, 同时借鉴国内外先进经验, 开展调蓄池、人工湿地、污水管网等设施的建设和 连通. 在此基础上, 叠加源头海绵城市设施, 在微 观层面进行精细化全面提升.

深圳市结合海绵城市生态安全格局与生态本 底, 划定了深圳市 6 类海绵城市功能分区并提出了 建设指引, 明确了海绵城市空间管控要求; 将年径 流总量控制率等目标分解到全市 9 大流域、25 个管 控片区，提出了分级分类的指标管控要求; 划定了 24 个海绵城市建设重点区域, 对全市海绵城市基础 设施建设项目进行指导 ${ }^{[10]}$.

\subsection{3 立足规划引领，加强顶层设计}

针对深圳市雨水管网存在的问题进行阶段性安 排与调整, 在维持城市社会经济正常运转的同时, 最大化发挥有限城市空间对雨水蓄滞的能力. 对接 国土空间规划体系, 将海绵城市建设要求与国土空 间规划相衔接, 落实和布局相关的海绵城市格局. 结合深圳现状, 做实管网普查, 推动片区排水系统 接驳完善, 做好雨污分流, 补齐排水管网欠账, 做 足源头减污, 实施排水户正本清源, 做强环保水务 管理，清除违法污染源.

\subsection{4 充分整合资源，打造海绵城市经济}

充分整合资源, 规范 PPP 等运营模式, 给予雨 水利用项目政策支持, 做通信息化网络, 实现管网 智慧运营, 创新性打造现代化的海绵城市产业链. 比如, 腾讯和华为等公司全面参与了深圳海绵城市
建设, 使得深圳海绵城市设施的智慧程度高于全国 其他城市.

根据海绵城市项目类别建立收费价格标准制度 体系, 建立运营维护费用保障机制, 确定政府补贴 标准, 健全价格调整机制和政府补占、监管机制, 广泛吸引社会资本参与海绵城市建设和运营.

\subsection{5 促进社会参与, 实现共治共享}

海绵城市的建设离不开群众的参与, 深圳推行 海绵城市教育活动, 建立全社会共同建设海绵城市 的意识, 推行 “海绵系列” 主题活动, 加速易推广 人群的引导. 深圳市充分发挥环保举报热线和网络 平台作用, 强化公众监督, 要求相关责任部门限期 办理群众举报投诉的环境问题, 一经查实, 给予举 报人奖励. 自觉接受人大代表、政协委员和市民群 众的监督, 加大环境水务违法案件的嚗光力度.

\subsection{6 合理安排资金，加强绩效考核}

经过 3 年海绵城市建设跟踪审计, 深圳市在中 央补助资金使用过程中未发现违规行为, 实现了预 期的经济效益、社会效益和生态效益, 建立了长期 有效的海绵城市建设管控措施. 为积极发挥海绵城 市建设试点补助资金使用效益, 深圳市海绵办、市 财政委员会、光明区积极加强与财政部驻深专员办 的沟通协调, 总结 3 方面经验: (1) 读懂政策, 明确 中央专项补助资金使用期限, 即在不超过存量资金 盘活年限（2 年）内按照项目建设进度开支使用; (2) 制定资金使用管理办法, 按照要求管理资金, 财政部门做好资金使用拨付和监督工作，政府部门 简化内部流程, 提高审批效率, 加快资金支出; (3) 市财政部门立足本职工作, 加大对市、区海绵办预 算资金支持, 以及试点建设项目相关建设单位的资 金使用督办考核力度, 以推动各试点项目建设有效 实施.

\section{3 深圳市海绵城市创新}

深圳市海绵城市创新包括组织管理创新和技术 创新, 而技术创新包括规划设计和施工技术创新. 组织管理创新包含组织和管理两方面, 在组织创新 方面, 深圳市创新地组建市、区海绵城市建设工作 领导小组、海绵城市建设技术联盟和企业院士工作 站, 管理创新包括制度和标准的制订等内容, 技术 创新主要是海绵城市设施设计创新和施工技术的创 新, 体现在海绵城市设施构造和海绵介质土创新. 


\section{1 组织管理创新}

在组织创新方面, 深圳市海绵办邀请国内外科 研机构和专家参与深圳海绵城市建设工作, 组织成 立海绵城市建设技术联盟，服务深圳市海绵城市建 设. 2016 年 11 月，市海绵办与清华大学、北京大 学和哈尔滨工业大学等 8 家单位签订海绵城市建设 技术联盟合作协议；2017 年 5 月，又与北京泰宁科 创雨水利用技术股份有限公司和深圳大学建设工程 生态技术研究所等 5 家单位签订了海绵城市建设技 术联盟合作协议．技术联盟成员单位先后为深圳市 海绵城市建设工作提出共计 60 项技术建议，整理 形成 17 个研究类项目纳人近 3 年计划. 海绵城市 建设技术联盟成员的专家全面参与了每一年度的深 圳市海绵城市绩效考核工作. 2018 年 10 月 30 日， 深圳市科学技术协会评审出了 2018 年深圳市院士 (专家) 工作站建站企业，成立了首家具有深圳海 绵城市特色的 “企业院士工作站” 以支撑深圳市海 绵城市建设的基础理论研究, 并开展了“深圳市海 绵城市建设降雨径流规律及模拟方法研究” 和 “水 文监测数据分析及城市化地区产流变化规律研究” 两项科研课题 ${ }^{[7]}$.

在管理创新方面，深圳制定了许多具有深圳特 色的制度和标准. 结合深圳市的发展状况, 深圳市 建立了全过程参与管控海绵城市建设制度、PPP 融 资制度和 “绩效考核、按效付费”机制等. 深圳市 利用大数据和云平台构建海绵城市智慧管控平台, 全过程参与海绵城市的设计、建设与监管，做到全 程监管，全域推进，高效快速的推进海绵城市的发 展. 海绵城市智慧管控平台包含 3 大支撑系统和 5 大应用系统平台: 大数据中心、数据挖掘与模型系 统、海绵城市 3D 展示系统，项目全生命周期管理 系统、绩效考核评估系统、黑臭水体监管系统、防 洪排涝管理系统. 深圳市首次采用 PPP 项目打包成 系统模式，要求项目边界清晰、政府与社会资本权 责明确、存量项目与新增项目兼顾、绩效目标明 确. “绩效考核、按效付费” 机制设计，PPP 项目 要求政府对社会资本实施 “绩效考核，按效付费”, 有效倒逼社会资本加大技术投人，保障项目实施绩 效, 加强运营管理, 进而实现压实责任主体, 㿞动 社会资本，解决了项目质量和进度问题等多方面的 综合效益.

\section{2 技术创新}

在海绵城市设施创新方面，深圳市结合深圳特 色，对海绵城市设施不断改进创新，针对建筑与小
区、道路与广场、公园绿地、旧改项目和水务项目 分别设计了许多创新性设施，如位于深圳大学沧海 校区的世界首创生态屋顶（不用浇水、不用施肥、 不用维护的绿色屋顶）、建筑垃圾制成的透水砖路 面、多功能蓄水池（具有湿地功能且可调节蓄水水 位的景观湖）、可调节出水流量的生物滞留设施等; 光明区地铁 6 号线长圳车辆段的创新海绵设施 (与 虹吸式落水管相连接的高位雨水花坛、生态雨水 篦）；南山区登良路全断面海绵城市设施（自然排 水系统和透水铺装); 甲子塘村统筹源头-过程-末端 的综合治理体系.

在海绵介质土研究应用方面，2012 年 10 月， 深圳大学建设工程生态技术研究所结合深圳的实际 情况，研制了水厂底泥、椰糠、竹子、砂土和当地 土等组成的新型海绵介质土, 并应用于深圳大学土 木结构实验楼和登良路海绵城市设施. 海绵介质土 渗透率大于 $25.4 \mathrm{~mm} / \mathrm{min}$, 有机质含量 $10 \%$ （体积 分数) 以上, 满足海绵城市设施透水和种植要求. 8 年的实践表明，这种海绵介质土优于传统的种植 土. 目前，这种新型介质土以及其改进配方已被广 泛应用于深圳、东莞、广州、珠海、镇江、西咸新 区和武汉等地的海绵城市设施.

\section{4 案例分析}

\section{1 深圳大学土木结构实验楼海绵城市设施}

\subsection{1 工程概况}

深圳大学土木结构实验大楼占地约 $1.3 \mathrm{hm}^{2}$, 包括西侧的结构实验大厅、北侧、中间和南侧的建 筑物和 $907 \mathrm{~m}^{2}$ 的景观庭院，楼顶总面积约 4025 $\mathrm{m}^{2}$. 该项目由深圳大学建筑设计研究院设计, 深圳 市林外林园林工程有限公司施工, 深圳大学建设工 程生态技术研究所提供技术指导 ${ }^{[11]}$. 该项目是中 国首个具有实时数据采集系统的海绵城市设施（当 时称作低影响开发设施）项目，可以评估不同海绵 城市设施性能 ${ }^{[12]}$. 工程于 2012 年 7 月 16 日开工, 同年 10 月土建工程完工，2013 年 4 月竣工，被美 国《World Water》列为 2013 年度世界 4 个暴雨管 理经典案例之一 ${ }^{[13]}$.

\subsection{2 海绵城市创新设计}

深圳大学土木结构实验楼海绵城市设施由设置 在屋顶和地表的海绵城市设施和观测监测设备组 成, 主要包括生态屋顶、蓝色屋顶、生物滞留池、 自然排水系统、雨水花园、透水铺装、蓄水箱和多 
功能蓄水池（图 1). 由于西侧的结构实验大厅存 在许多裂缝, 在兴建生态屋顶的过程中出现漏水, 不得不临时修改生态屋顶的构造设计，将生态屋顶 改造为由建筑垃圾制成的透水砖和粗砂等构成的蓝 色屋顶．南侧和中间屋顶上修建生态屋顶，总面积 共 $1100 \mathrm{~m}^{2}$. 中央庭院内的地表海绵城市设施由两 条透水铺装路面、3 个生态滞留池、2 个雨水箱、1 条自然排水系统、 1 个雨水花园和 1 个多功能蓄水 池等组成 ${ }^{[14-15]}$.

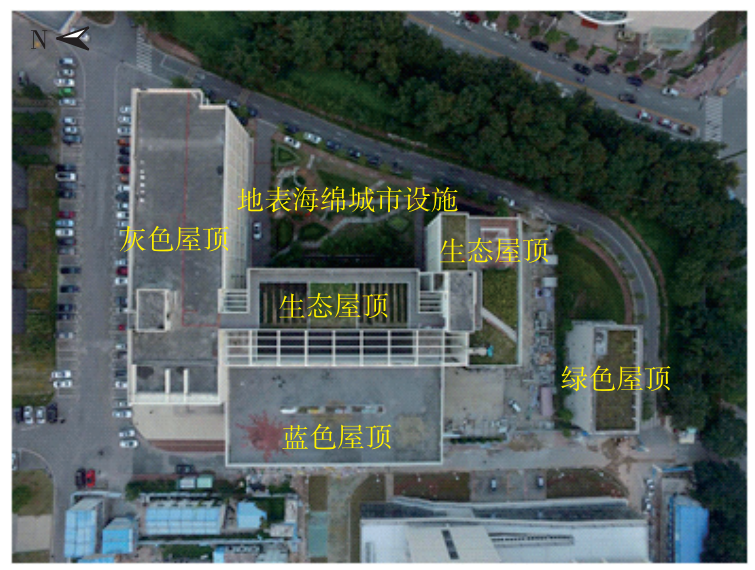

图 1 深圳大学沧海校区海绵城市设施俯视图

Fig. 1 Sponge city facilities in Shenzhen University

生态屋顶、蓝色屋顶和地表海绵城市设施按 25 年一遇最大日降雨量 $(387 \mathrm{~mm})$ 进行设计, 蓄水 能力按照历史 $1 \mathrm{~h}$ 最大降雨量 $(99.4 \mathrm{~mm})$ 设计, 同时解决了暴雨储留和小雨净化的问题. 该设计同 时考虑了城市防洪和雨水利用两个方面的需求, 为 海绵城市的设施提供了一个薮新的设计标准.

布置在南楼与中间连楼的生态屋顶厚 $25 \mathrm{~cm}$, 其表层与边墙顶部有 $15 \mathrm{~cm}$ 的高差，暴雨期间可以 滞留大量的雨水. 该生态屋顶由耐旱植物、种植层 (生长介质)、阻根层、砾石层、聚氯乙烯 (polyvinyl chloride, PVC) 花管和防水层构成，在出水端设 置了多个创新的出流控制装置（图 2)，该装置可 以转动, 用以调整生态屋顶出水流量和控制雨水滞 留在底部碎石层的时间. 在生长介质上进行了创 新, 采用沙土、稀土矿渣 (镂) 、水厂底泥和椰糠 等进行合理配比，组成 3 种不同配方的海绵介质 土. 经过生态屋顶处置的雨水水质满足 《地表水环 境质量标准》 GB 3838-2002 II 类水指标, 削减暴 雨径流 30\% 50\%，延长峰值约 $20 \mathrm{~min}$, 减小峰值 $1 / 3 \sim 1 / 2$. 生态屋顶在 2014 年 11 月获得第十六届 中国国际高新技术成果交易会优秀成果奖. 南侧和
中间的生态屋顶净化后的部分雨水流人设置在地表 的两个雨水罐，用于浇灌地表植物.

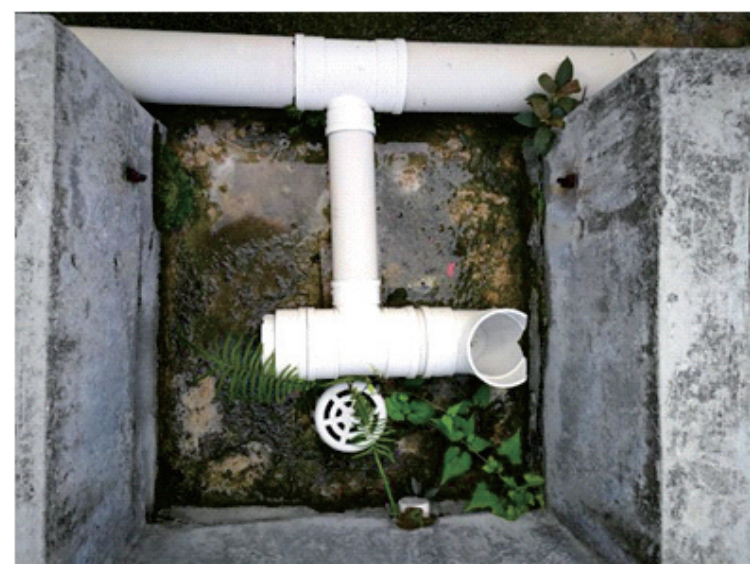

图 2 生态屋顶出流控制装置

Fig. 2 Outflow control device of ecoroof

地表海绵城市设施由 3 个生态滞留池、自然排 水系统、雨水花园、2 条透水铺装路面、1 个多功 能蓄水池 (南侧为人工湿地) 和 2 个体积为 $2 \mathrm{~m}^{3}$ 雨水罐等组成. 生物滞留池用于处理北侧大楼未绿 化屋顶 (约 $1300 \mathrm{~m}^{2}$ ) 的雨水, 由分流设施、植物 (菖蒲)、海绵介质土、碎石层、排水穿孔管及出流 控制装置等构成. 该设施除处理雨水外，还可以处 理则所的上清液. 自然排水系统将生物滞留池流出 的水和部分地表径流输送至下游的雨水花园. 雨水 花园用于处理园区内的地表径流和进一步净化来自 上游自然排水系统的雨水，由植物（再力花、芦 苇、风车草和菖蒲)、 $45 \mathrm{~cm}$ 厚的混合土、15 cm 厚 碎石和 $15 \mathrm{~cm}$ 厚的粗砂组成. 通过碎石层内的穿孔 管将水排人多功能调节池. 多功能调节池用于收 集、调节园区内和周边屋顶的雨水，平时亦可用作 观赏，收集而来的雨水可用于灌溉. 南侧的湿地用 于净化水质，东侧设置有溢流口和放空口. 设置在 南北两侧的透水铺装路面由建筑垃圾制成的透水 砖、碎石透水层和排水花管铺成.

\section{1.3 效果及经验}

自 2013 年 4 月建成以来，深圳大学土木结构 实验楼海绵城市设施经历了多场暴雨的考验. 特别 是经受了 2014 年 5 月 11 日特大暴雨的洗礼，这次 强降雨全市平均累计降雨 $226 \mathrm{~mm}$, 降雨中心最大 累计降雨量超过 $430 \mathrm{~mm}$ ，相当于 50 年一遇的暴雨 强度. 深圳大学校园内积水严重, 有些地方积水深 度达 $20 \mathrm{~cm}$ 以上，但土木结构实验楼海绵城市设施 周边区域则没有造成任何积水，大大减轻了市政管 
网的压力. 同样, 2018 年 9 月的台风 “山竹” 是 1983 年以来影响深圳最强的台风, 最大风速 17 级, 局部降雨量 $300 \mathrm{~mm}$ 以上, 最大降雨强度 $70 \sim 90$ $\mathrm{mm} / \mathrm{h}$, 该次降雨深圳大学校园内也出现严重积水, 但土木结构实验楼海绵城市设施周边区域则没有出 现任何积水和影响. 验证了采用 25 年一遇最大日 降雨量设计标准的正确性.

深圳大学土木结构实验楼海绵城市设施在实施 过程中取得了如下的经验: (1) 项目采取设计、施 工一体化招标，减少了沟通环节。 (2) 由于施工人 员缺乏海绵城市知识, 无法正确理解图纸内容, 施 工质量一般. 因此, 施工前应对项目经理和主要施 工人员进行培训. (3) 在项目建设中大量采用了固 体废弃物，例如透水铺装路面和生态屋顶的人行道 采用了建筑垃圾制成的透水砖，植被生长介质大量 采用了水厂底泥，部分装饰用材料则利用了废弃的 易拉罐. (4) 项目将教学实验、教育示范、环境改 善结合起来，取得了良好的社会效益. (5) 没有照 搬美国标准，而是因地制宜地提出了适宜于台风地 区的设计标准.

\section{2 登良路海绵城市设施}

\subsection{1 工程概况}

登良路工程位于深圳市南山区，属于深圳市后 海湾填海区 (北区) 市政工程, 道路类型为双向 4 车 道, 绿化面积约为 $18450 \mathrm{~m}^{2}$. 与传统道路不同, 海绵城市设施是登良路道路工程的一部分，道路两 侧的慢行系统均采用透水混凝土铺装，绿化带均按 海绵城市设计，包括位于道路两侧的绿化带、侧分 带和中央隔离带的自然排水系统和创业路与登良路 交叉路口的雨水花园和下凹式绿地 (图 3). 海绵城

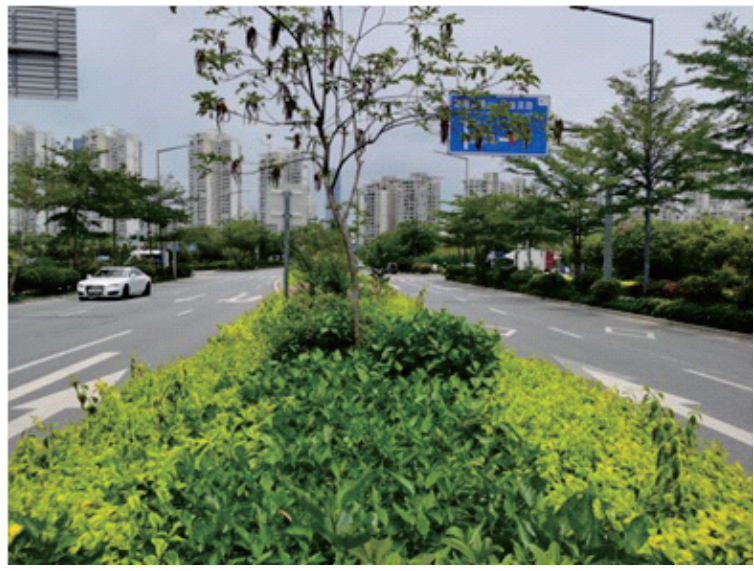

图 3 登良路中央隔离带自然排水系统

Fig. 3 Natural drainage system in the middle of the Dengliang Road
市设施于 2015 年 3 月正式动工, 2017 年 9 月竣工.

\section{2.2 海绵城市创新设计}

登良路海绵城市设施技术方案由深圳大学建设 工程生态技术研究所提供. 暴雨设计标准采用 25 年一遇年最大日降雨量 $(387 \mathrm{~mm})^{[16]}$. 为了在原有 景观基础上不占用额外的空间且能达到处理雨水径 流的效果，所有海绵城市设施均设置在绿化带内， 不改变原来道路工程设计 ${ }^{[17]}$ 。植物种植土采用配 置的混合土，有机质含量控制在 8\% 10\% (质量分 数) 内, 且自然排水系统表层石头覆盖层采用卵石 铺设, 厚 $20 \sim 50 \mathrm{~mm}$. 由当地土、沙土、椰糠和水 厂底泥配制的种植土的渗透率大于 $25.4 \mathrm{~mm} / \mathrm{min}$, 充分保证雨水花园、自然排水系统内的地表积水在 $24 \mathrm{~h}$ 内渗透至底部碎石排水系统 ${ }^{[18]}$. 为保证道路 建成后进行流量观测与水质监测, 在 $1.2 \mathrm{~km}$ 长的 线路上设置 3 个流量观测与水质监测井.

登良路海绵城市设施案例改变传统道路设计模 式，采用自然排水系统和雨水花园处理路面径流和 雨水污染, 为道路雨水设计提供了一种新方法.

\section{2.3 效果及经验教训}

作为深圳中心城区第 1 条海绵路，登良路为深 圳建设海绵城市起到了示范作用. 登良路建成之 后，经过多场大雨的考验，下凹式绿地、雨水花 园、透水铺装路面、自然排水系统运行情况良好, 未出现滞水现象. 不仅有效减轻防洪排涝压力, 解 决道路积水问题，还可避免雨水资源流失，最大限 度吸收涵养水分.

登良路的实践表明：海绵城市建设理念与传统 的绿化种植要求需要相互协调. 海绵城市设施要求 采用下凹式地形进行蓄水, 而常规绿地整形时要求 修整成 “龟背” 状; 海绵城市设施不能种植根系发 达的高大乔木，而传统的绿化种植常选择根系发 达、胸径粗壮、树冠高大的树种，因此，需要将海 绵城市建设理念融人绿化种植. 经验教训是部分断 面未按图施工，种植土也没有按照要求进行配制, 导致部分断面渗透缓慢.

\section{3 长圳车辆段海绵城市设施}

\subsection{1 工程概况}

长圳车辆段位于科裕路以西(规划)、同观路以 南 (规划)、东长路以东、光侨路以北的围合地块, 是深圳市轨道交通 6 号线工程的重要工程之一，与 长圳站相邻，规划用途为住宅用地、商业用地和配 套的公共服务设施，用地总面积为 $24.94 \mathrm{hm}^{2}$, 总 建筑面积为 $233764.4 \mathrm{~m}^{2}$, 其中单体建筑面积 
$168713.5 \mathrm{~m}^{2}$, 规划面积 $148200 \mathrm{~m}^{2}$. 长圳车辆段 的海绵城市设计由深圳大学建筑工程生态技术研究 所承担, 考虑地铁车辆段的建设法规和地形, 综合 海绵城市传统设施，对海绵城市设施进行改进和创 新, 从而适应轨道交通海绵城市的建设 ${ }^{[19]}$. 长圳 车辆段海绵城市设施于 2019 年 12 月开工建设, 2020 年 5 月底竣工.

\section{3.2 海绵城市设施创新设计}

根据深圳地铁 6 号线长圳车辆段的工程场地特 点和施工方案, 针对地铁车辆段海绵城市设施进行 创新设计，建设了适合车辆段的生态屋顶、高位雨 水花坛（图 4)、植草沟、雨水花园、地表蓄水池 （景观湖）、地下蓄水模块等海绵城市设施. 限于篇 幅, 仅介绍专门为长圳车辆段设计的创新型高位雨 水花坛.

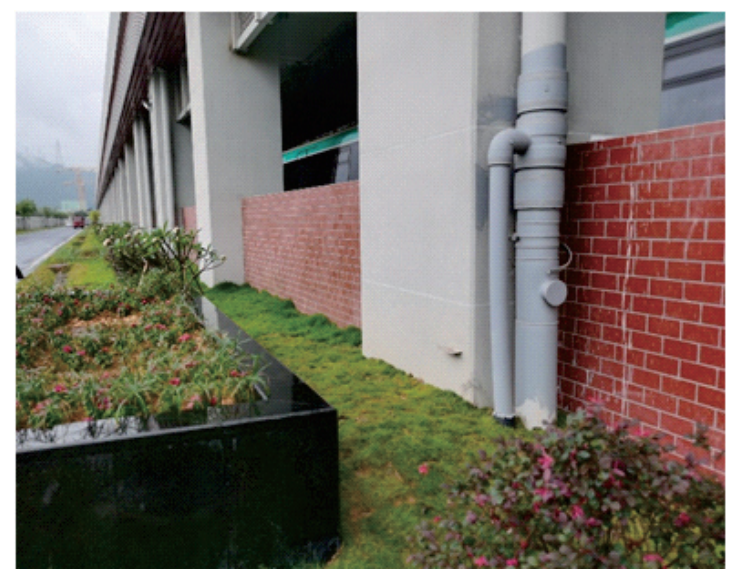

图 4 高位雨水花坛

Fig. 4 Elevated bioretention cell

高位雨水花坛同雨水花园具有相似的功能，均 可用于减少暴雨径流、削减暴雨径流峰值, 能够将 径流峰值出现的时间推迟，也能去除雨水径流中的 污染物. 高位雨水花坛的断面形状和构造与雨水花 园相似，但高于地表，不仅能用于处理建筑屋面的 雨水，还可用于超高层建筑屋顶雨水或者带有压力 的虹吸排水系统中的屋顶雨水.

在长圳车辆段周边建设了 4 个高位雨水花坛, 用于处理车辆段屋顶的部分雨水 ${ }^{[20]}$. 高位雨水花 坛由三通管（三通管连接虹吸式落水管，位置位于 0 压力点下方 $0.5 \mathrm{~m}$ 处)、植被层、种植土层和砾石 排水层组成. 其作用原理为：(1)通过三通管，将落 水管中的部分雨水引人到高位雨水花坛中的消能 井，用于耗散能量和减缓水流流速；(2)从消能井溢 流出来的水进人到植被层和介质层，经过植物的根
茎、土壤中的微生物净化后, 渗人砾石层; (3)再通 过砾石排水层中的穿孔管将雨水排人到右侧的溢流 控制井中，在溢流井内设置出流控制装置，当流量 很小时, 水从下部开口流出, 当流量变大时, 上部 开口也有雨水流出.

由于虹吸式落水管存在压力, 设计高位雨水花 坛时应精确计算三通管的接人位置, 否则会影响落 水管的正常运行.

\subsection{3 效果与经验}

根据长圳车辆段绿地面积小、不透水层面积大 的特点, 设计了可以满足国家海绵城市建设要求的 海绵城市设施.

对于轨道交通工程，不宜直接套用建筑小区海 绵城市建设标准和设施，应根据需要设计适用于轨 道交通项目的海绵城市设施. 减轻暴雨径流量的同 时，应考虑雨水、污水的净化利用.

\section{4 甲子塘村城中村综合整治项目海绵城市建设}

\section{4. 1 工程概况}

甲子塘片区是深圳市现存为数不多的超过 300 年历史的城中村，位于深圳市光明新区国家海绵城 市建设试点区域风凰街道，总面积约 $70 \mathrm{hm}^{2}$ ，居住 人口约 22000 人，其中 $90 \%$ 以上为外来务工人口， 人口密度 $\left(31000\right.$ 人 $\left./ \mathrm{km}^{2}\right)$ 远高于深圳市平均水 平 $\left(6000\right.$ 人 $\left./ \mathrm{km}^{2}\right)$. 区内工业企业 65 家，主要是 劳动密集型企业，是鹅颈水流域内典型的高密度、 难管理、环境差、改造难的老旧片区．随着城市无 序的扩张，原本低矮的旧村已扩张为高层建筑，与 此同时，由于粗放的管理导致整个片区水环境质量 较差、水安全风险较高、水生态价值不足和综合环 境较差等突出问题. 为破解上述问题，光明新区多 部门联合，在各部门专项行动中全面融合海绵理 念，打造城中村综合治理的典范，成为小流域系统 治理的探索先锋，并在 2019 年 4 月获得全国人大 常委会执法检查组的高度肯定，为全国城中村综合 治理贡献深圳智慧.

\section{4.2 统筹源头-过程-末端的治理体系}

为彻底改善社区综合环境，甲子塘片区项目抓 住地下管网先天不足的短板，按照 “治水先行，地 下先行” 工作原则，根据问题台账，合理制定整治 方案，以 “灰色基础设施强基、绿色基础设施提 标” 的总体思路，理顺社区排水系统，提升社区综 合品质. 针对工业区雨污合流、混流问题，纳人工 业区正本清源工程实施; 针对排水户仅有 1 套雨污 合流建筑立管问题，开展建筑立管改造；针对居民 
区排水户错接乱排问题，开展排水户接驳完善; 针 对市政排水管网不完善、堵塞、漏损等问题，立项 开展清掏、更换和优化完善; 针对排洪渠黑臭问 题，通过实施河道清淤、岸线改造、排口整治、生 态补水等措施，提升水环境质量，打造亲水空间. 同时最大化挖掘社区公共空间，融合海绵理念，因 地制宜落实源头海绵设施，提升公共空间品质，提 升社区居住环境，极大提升居民的幸福感，如图 5 和图 6 .

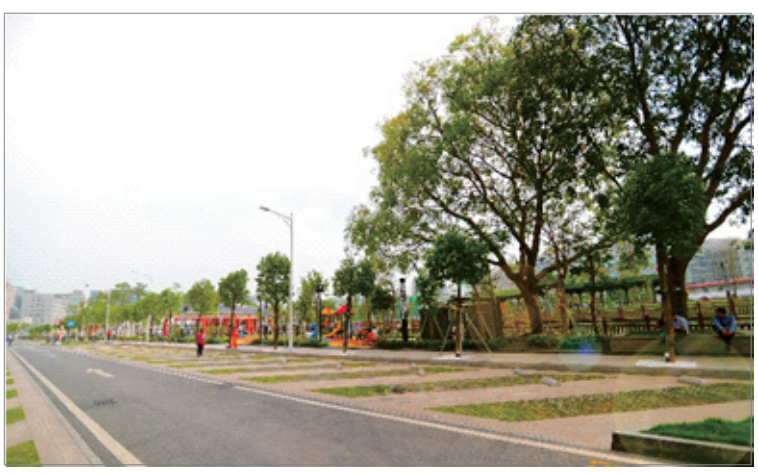

图 5 透水铺装

Fig. 5 Permeable pavement

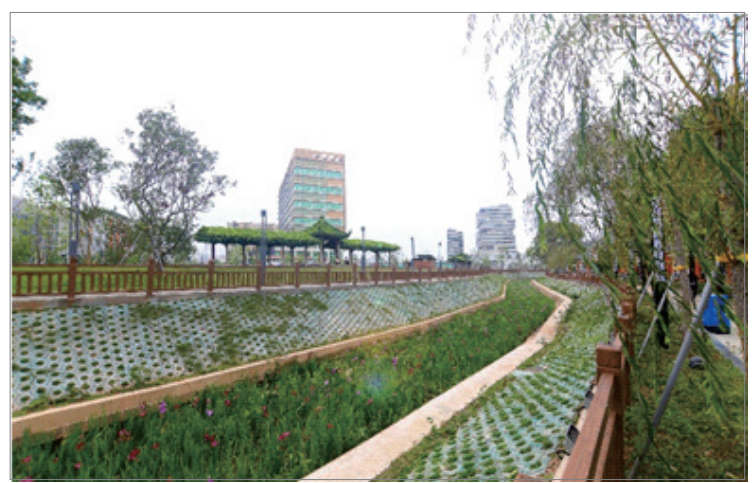

图 6 甲子塘片区海绵城市设施一一湿地与生态护岸

Fig. 6 Sponge city facilities in Jiazitang Village: wetland and ecological revetment

1) 源头减排

绿色设施: 对社区现有空地、闲散地、停车 场、破旧公园等因地制宜落实海绵设施，打造海绵 型公园绿地，累计改造绿地面积约 $10 \mathrm{hm}^{2}$.

灰色设施：对建筑立管实现 $100 \%$ 改造，从源 头实现雨污分流，累计改造建筑雨水立管 3640 根， 其中，城中村 2280 根，工业区 1360 根.

2) 过程控制

错接乱排整治：对城中村和工业区错接乱排改
造 15 处, 实现漏排污水全收集, 涉及 $708 \mathrm{~m}$ 污水 管和 $63 \mathrm{~m}$ 雨水管.

提高排水系统的运行效率：片区内 $41 \mathrm{~km}^{2}$ 的 排水管网全部移交 PPP 项目公司接管运维，提升管 网的运行效率，污水通过甲子塘大道 DN800 的干管 输送至光明水质净化厂.

\section{3) 末端治理}

甲子塘排洪渠综合整治：清淤 $5900 \mathrm{~m}^{3}$ ，生态 岸线改造 $1.4 \mathrm{~km}$, 岸线护坡修复，生态补水 2700 $\mathrm{m}^{3} / \mathrm{d}$ ，同时栽种菖蒲、美人蕉等水生植物，提升河 道景观效果.

截至 2019 年 2 月，甲子塘片区涉及的 10 个项 目先后完工，涉及投资约 1.5 亿元.

\section{4.3 保障长久效益的创新管理措施}

在这样一个复杂的城中村，仅仅依靠工程措施 还远远不够. 为此, 光明新区从机制着手，提出 “水务管养进社区” 新模式，将全区划分成 34 个网 格，派驻水务管养人员 403 人，配备巡查车 135 辆、抢修车 53 辆和清疏车辆 10 台等设备, 全面承 担排水设施日常巡查、养护、排水户登记管理、排 水宣传和涉水违法事件上报协同处置等工作，实现 了“划片管理、网格服务、定点管控、责任到人”. 联合水务、城管、查违、生态等职能部门以及街 道、社区、水务网格等，建立专项行动常态化联动 机制，对 7 大类 13 种违法排水行为开展专项排查, 严厉打击各种违法排水行为. 正是通过这一系列 “工程 + 管理” 的举措, 最终实现纠正不良的排水 行为、转变传统的排水意识、养成良好的排水习惯 的目标，实现甲子塘片区的长制久清.

\section{结 语}

经过多年的研究和实践, 深圳市海绵城市建设 取得了巨大的成就，积累了丰富的建设经验. 已建 成的海绵城市设施不但在数量上名列前茅, 而且设 施种类繁多，技术先进.

2019 年底, 深圳市海绵城市建设面积超额完成 2020 年国家海绵城市建设目标, 并顺利地通过国家 海绵城市试点考核. 在推进海绵城市建设过程中制 订的政策文件和技术标准不但指导了深圳市海绵城 市建设，而且为粤港澳大湾区海绵城市建设提供了 借鉴. 因地制宜创造的新型海绵城市设施不但丰富 了海绵城市设施的类型，而且提高了海绵城市设施 效益. 
海绵城市建设经验可为广东省万里碧道建设提 供借鉴. 碧道是广东省委、省政府落实习近平总书 记 “绿水青山就是金山银山” 的生态文明思想的具 体实践，海绵城市设施是碧道工程的主要组成部 分. 因此，在规划设计建设海绵城市设施时，可考 虑与碧道建设相结合, 探索二者之间的融合之路, 避免重复建设.

需要指出的是, 海绵城市设施对于消减径流污 染物有显著效果，且不同的海绵城市设施对各种污 染物的去除率有明显差异 ${ }^{[21]}$. 但是, 目前我国建 成的海绵城市项目, 普遍缺乏监测设施, 不能对海 绵城市设施的运营情况和污染物的去除情况进行监 测分析, 影响对海绵城市设施的客观评价, 因此, 有必要加强海绵城市智能化监测工作.

基金项目: 国家重点研发计划资助项目（2018YFB2100901）

作者简介: 刘 建 (1965一), 深圳大学教授. 研究方向: 海绵城 市、固体废弃物资源化和水环境治理. E-mail: liujian@ szu.edu.cn

吴凌壹 (1982-) , 深圳大学实验师. 研究方向：海绵 城市、BIM 和智慧建造. E-mail: szuly@ szu.edu.cn

引文: 刘 建, 龚小强, 任心欣, 等. 深圳市海绵城市的建设 与创新 $[\mathrm{J}]$. 深圳大学学报理工版, $2020,37(4)$ : 334346.

\section{参考文献 / References:}

[ 1 ] SHAFIQUE M, KIM R. Low impact development practices: a review of current research and recommendations for future directions $[\mathrm{J}]$. Nephron Clinical Practice, $2015,22(4)$ : 543-563.

[ 2 ] U. S. Environmental Protection Agency. Green infrastructure in parks: a guide to collaboration, funding, and community engagement $[R]$. EPA 841-R-16-112, Washington: USEPA, 2017.

[ 3 ] 习近平. 习近平谈生态文明 [EB/OL]. (2014-0829) [ 2020-05-06 ] http://cpc. people. com. cn/n/2014/ 0829/c164113-25567379-3. html.

XI Jinping. XI Jinping talk about ecological civilization [EB/OL ]. (2014-08-29) [2020-05-06 ]. http://cpc. people. com. cn/n/2014/0829/c164113-25567379-3. html. (in Chinese)

[ 4 ] 中华人民共和国住房和城乡建设部. 中央财政给予海 绵城市试点专项资金补助 [EB/OL]. (2015-01-20) [ 2020-05-01 ]. http://www. mohurd. gov. cn/zxydt/ 201501/t20150120_220164. html.

Ministry of Housing and Urban Rural Development of the People's Republic of China. Central finance grants special funds to pilot sponge cities $[\mathrm{EB} / \mathrm{OL}]$. (2015-01-20)
[ 2020-05-01 ]. http://www. mohurd. gov. cn/zxydt/ 201501/t20150120_220164. html. (in Chinese)

[ 5 ] 深圳市统计局. 深圳市 2018 年国民经济和社会发展统 计公报 [EB/OL ]. (2019-04-19) [2020-05-01 ]. http://www. sz. gov. cn/sztjj2015/zwgk/zfxxgkml/tjsj/ tjgb/ 201904/t20190419_16908575. htm.

Shenzhen Municipal Bureau of Statistics. Bulletin of national economic and social development statistics of Shenzhen in 2018 [ EB/OL]. (2019-04-19) [ 2020-0501 ]. http://www. sz. gov. cn/sztjj2015/zwgk/zfxxgkml/ tjsj/tjgb/201904/t20190419_16908575. htm. (in Chinese)

[6 ] 深圳市水务局. 深圳市水务局 2017 年工作总结与 2018 年工作计划 [EB/OL]. (2018-05-18) [2020-0501 ]. http://swj. sz. gov. cn/xxgk/zfxxgkml/lsgd/ghjh/ 201805/t20180518_11921543. htm.

Shenzhen Municipal Water Bureau. 2017 work summary and 2018 work plan of Shenzhen Water Bureau [EB/OL ]. (2018-05-18) [2020-05-01 ]. http://swj. sz. gov. cn/ xxgk/zfxxgkml/lsgd/ghjh/201805/t20180518 _ 11921543. htm. (in Chinese)

[ 7 ] 深圳市水务局. 深圳市水务局 2018 年工作总结与 2019 年工作计划 $[\mathrm{EB} / \mathrm{OL}]$. (2018-06-06) [2020-0501 ]. http://swj. sz. gov. cn/xxgk/zfxxgkml/ghjh/ndgzjhjzj/201906/t20190606_17870692. htm.

Shenzhen Municipal Water Bureau. 2018 work summary and 2019 work plan of Shenzhen Water Bureau [EB/OL]. (2018-06-06) [2020-05-01 ]. http://swj. sz. gov. cn/xxgk/ zfxxgkml/ghjh/ndgzjhjzj/201906/t20190606_17870692. htm. (in Chinese)

[ 8 ] 深圳市水务局. 重温海绵城市建设初心, 助力深圳高 质量发展一一市海绵城市建设工作领导小组第八次会 议召 开 [ EB/OL ]. (2020-04-20) [ 2020-05-01 ]. http://swj. sz. gov. cn/xxgk/zfxxgkml/gzdt/202004/ t20200420_19177883. htm.

Shenzhen Municipal Water Bureau. Review the original intention of sponge city construction and help Shenzhen develop with high quality: the eighth meeting of the leading group of sponge city construction was held [EB/OL] (2020-04-20) [2020-05-01 ]. http://swj. sz. gov. cn/xxgk/zfxxgkml/gzdt/202004/t20200420_19177883. htm. (in Chinese)

[ 9 ] 深圳市人民政府. 深圳市海绵城市建设试点绩效自评 总报告 $[R] .2019$.

Shenzhen Municipal People's Government. Self-assessment general report of Shenzhen sponge city construction pilot performance $[R]$. 2019. (in Chinese)

[10］曾小瑱, 谢家强. 拆除重建类城市更新项目海绵城市 
规划编制——深圳市为例 $[J]$. 城乡建设, 2018, $541(10): 35-38$.

ZENG Xiaozhen, XIE Jiaqiang. Sponge city planning of dismantling and rebuilding urban renewal project taking Shenzhen as an example $[\mathrm{J}]$. Urban and Rural Studies, 2018, 541 (10) : 35-38. (in Chinese)

[11] RUKMANA D. The routledge handbook of planning megacities in the global south: master plan of the sponge city in Shenzhen $[\mathrm{M}]$. London: Routledge, 2020: 1422.

[12] 深圳市规划和国土资源委员会. 深圳市海绵城市建设 专项规划及实施方案 [EB/OL]。(2017-09-25) ［202005-01 ]. http://www. sz. gov. cn/cn/xxgk/zfxxgj/ghjh/ csgh/zxgh/content/post_1317061. html.

Shenzhen Planning and Land Resources Commission. Special planning and implementation plan for sponge city construction in Shenzhen [EB/OL]. (2017-09-25) [202005-01 ]. http://www. sz. gov. cn/cn/ xxgk/ zfxxgj/ghjh/ csgh/zxgh/content/post_1317061. html.

[13] 刘 建，韩雨停，苏艳娇，等. 中国华南地区低影响 开发设施典型案例分析 $[\mathrm{J}]$. 景观设计学, 2015, 3 (4) : 30-39.

LIU Jian, HAN Yuting, SU Yanjiao, et al. Low impact development facilities in Guangdong Province, China [J]. Landscape Architecture Frontiers, 2015 , 3(4) : 3039. (in Chinese)

[14] LIU Jian, SHE Nian. Shenzhen University pilots LID for urban retrofits $[\mathrm{J}]$. World Water: Stormwater Management, 2013, 1(1) : 24-25.

[15] LUCAS W, SHE Nian, LIU Jian. Advanced LID experimental array: Shenzhen University, Guangdong Province, China $[\mathrm{C}] / /$ World Environmental and Water Resources Congress. Albuquerque, USA: [s.n. ], 2012: $203-$ 2012.

[16] LIU Jian, CHEN Shicong, WU Lingyi, et al. Innovative design of a suite of low impact development facilities in civil structure experimental building complex $[\mathrm{C}] / /$
Proceedings of the 17th International Symposium on Advancement of Construction Management and Real Estate. Berlin: Springer, 2014: 859-866.

[17] 刘 建，李四新，陈 慧，等. 市政道路低影响开发 设施设计案例分析 $[\mathrm{J}]$. 中国给水排水, 2017, 33(4)： 14-19.

LIU Jian, LI Sixin, CHEN Hui, et al. Case study of low impact development facilities for municipal roads $[\mathrm{J}]$. China Water \& Wastewater, 2017, 33 (4): 14-19. (in Chinese)

[18] 苏艳娇, 李四新, 韩雨停, 等. 减轻城市内涝和面源 污染的低影响开发技术 $[\mathrm{J}]$. 防灾减灾工程学报, 2016, 158-164.

SU Yanjiao, LI Sixin, HAN Yuting, et al. Reducing urban waterlogging and non-point source pollution by low impact development technniques $[\mathrm{J}]$. Journal of disaster prevention and mitigation engineering, 2016, 158-164. (in Chinese)

[19］刘 燕. 适用于城市轨道交通项目的海绵城市设施研 究——以深圳地铁 6 号线长圳车辆段为例 [D]. 深圳: 深圳大学, 2019 .

LIU Yan. Research on sponge city facilities suitable for urban rail transit projects: take Changzhen depot of Shenzhen metro line 6 as an example [D]. Shenzhen: Shenzhen University, 2019. (in Chinese)

[20］中国建筑工业出版社. GB/T51345-2018 海绵城市建 设评价标准 $[\mathrm{S}]$.

China Construction Industry Press. GB/51345-2018 Sponge city construction evaluation standard $[\mathrm{S}]$. (in Chinese)

[21 ] CLARY J, JONES J, LEISENRING M, et al. International stormwater BMP database: 2016 summary statistics [R]. Project \#1136, Denver: The Water Research Foundation, 2016.

【中文责编：晨 兮; 英文责编：新 谷】 